\title{
GREEN HRM:A NEW TREND IN ENHANCING GREEN BEHAVIOUR AT WORKPLACE
}

\author{
Dr. Shweta S. Kulshrestha
}

Assistant professor, Ph.D. (HR), Mangalmay Institute of Management And Technology, Greater Noida.

\section{Shruti Srivastava}

Assistant professor, MBA (HR), Mangalmay Institute of Management And Technology, Greater Noida.

\section{Abstract:}

This paper seeks to attempt simplified reflections on the concept of green human resource management (Green HRM) that is a great concept which helps to sustain our environment and if worked on that have a great potential to serve initially the individuals then to the society and largely on the environment along with the business. The paper just focuses to explore the basics of this concept such as the meaning of the green HRM, reasons for moving towards greening, importance of green HRM, greening of HRM functions and requirements and the findings of some green HRM studies done in past by great researchers. We hope that this paper have some utility and engenders an interest within the potential researchers and even to the people who want to explore the concept of green HRM.

Key words: Greening, Human Resource Management and environmental management.

\section{INTRODUCTION:}

We are entering into the world were in a green economy will be there which consists - consumers and employees expectations and the future environmental changes will stress on the business to address some "green" issues in their organisations. Green HRM not only focuses on the reduction of carbon footprints of each employee and to retain talent but also has two vital elements: environmental friendly HR practices and the preservations of the knowledge capital.

The Green HR practices involves reducing the usage of carbon footprints by less printing of paper, using more of technologies for communication and moving towards online interviewing and mailing. But the most important thing is also to retain the top talents in the organisations which are facing problems in the current scenario where in the companies are facing the problem of preserving the knowledge capital.

Moving towards the green HRM helps the organisation to reduce the cost without losing their top talent, speed their processes through technology and making the employees more concisous and aware about the environmental and climatic changes. Thus being green helps the organisation to hold on the employees rather than considering them as expendable asset.

Following this concept is a win/win situation for the employee as well as the employer. As they are able to maintain the top employees and they are in turn happy for that and they become more 
productive. The main requirement needed from the side of the employer is strong leadership, care for their employees, offer professional growth along with opportunities bringing more responsibilities and must be paid off for the hard-work done by the employee.

The main focus of green HRM is to reduce the waste and optimise the use of the resources. This can be proved as business fulfilling its great objective of towards its stakeholders and specially towards the society by protecting the environment. As it's a known fact that alone department cannot achieve anything and behind every great achievement there is a great team work. So to be green the whole organisation have to put the efforts for the same.

Green HRM is moreover a part of fulfilling the corporate social responsibility. The topic of sustaining the environment is attracting the management scholars. Thus there is a growing need on exploring and deeply understanding the concept of green HRM. This paper focus on addressing the following questions with the approach of being reflective, descriptive and perspective. Such things are What is green?, Why is green?, what is green HRM?, Why there is a need of the same in $21^{\text {st }}$ Century?, how to convert the functions to green HRM functions?, and finally considering some of the findings done so far on the same.

\section{LITERATURE REVIEW:}

The impact of our daily activities on the environment and the desire to become green has expanded from individuals to organizations. More organizations are becoming voluntary to operate in a more responsible way with the environment. Local municipalities are encouraging businesses to be greener by offering incentives. In the near future, "being green" could become the norm. In September 2007, the Society of Human Resources Management (SHRM) conducted the Green Workplace Survey of SHRM 2007 to examine environmentally responsible practices from the perspective of HR professionals and employees.

Green HR is one that involves two essential elements, HR practices that respect the environment and the preservation of knowledge capital. Business professionals consider it environmental initiatives to reduce employees' carbon footprint.

In the past, it was expected that the solid economic performance of the company would guarantee the corporate success of the companies and their shareholders, but now it is no longer valid; economic and financial results must be accompanied by a minimization of ecological footprints and greater attention to social and environmental aspects. Therefore, the new strategic theme, corporate environmentalism or ecological management emerged in the 1990s and became a popular slogan internationally in 2000 (Lee, 2009). Green management is defined as the process by which companies manage the environment by developing environmental management strategies (Lee, 2009) in which companies need to balance industrial growth and safeguard the natural environment for the future generation to prosper (Daily and Huang, 2001). This concept becomes a dominant strategic issue for companies, especially multinational companies that operate their businesses worldwide (Banerjee, 2001).

In summary, green management refers to the management of corporate interaction and impact on the environment (Lee and Ball, 2003) and has gone beyond regulatory compliance and should include conceptual tools such as pollution prevention, product management and responsibility (Hart, 2005, Pullman et al., 2009, Siegel, 2009). 
Therefore, companies should strive more in research on innovative technology to minimize the impacts of environmental destruction by creating products that are non-toxic and less polluting for the environment (Liu, 2010; Ozen and Kusku, 2008.)

\section{BENEFITS OF GREEN HR INITIATIVE:}

Today some of the activities of HRM have become vital for the business to perform who have become a standard for Green HRM :

1. Use of telephone - or video calling - for the pre interviewing so that companies can do pre screening of the candidates, in order to minimize the environmental impact od travel.

2. Mailing and using the other internet facilities like fax for the office works so that the unnecessary usage of printing of papers can be avoided.

Thus there are also some HR policies that dadicate and/ or reward the employees environmental friendly

Following are the benefits:

1. Employees can be recommended to start making changes at home and then observe how they practice environmentally responsible behaviours at work. Once you witness significant energy savings from solar panels or the Energy Star-rated refrigerator, you are more likely to buy the value of saving energy and resources at home and at work.

2. Employees may be asked to suggest ways in which the organization can turn green. Example: companies can start a team of ugreen employees "that can attract some volunteers from the workforce of employees and part of them. The group can meet monthly to bring changes such as the addition of transportation incentives and the use of paperwork recycled.

3. Publicly congratulate the employees who take advantage of the ecological benefits of the company and then publish a quarterly online newsletter dedicated exclusively to their stories and remind workers about the ecological benefits and how to participate. By doing so the employee will be motivated to do the same in future and others gets to learn from their behaviour and there may be chances for them to change their behaviour.

4. The HRM can create a green Infrastructure so that they can maintain the environment and also help to enhance the surroundings there in.

5. Everyone can be informed about green benefits like job candidates,shareholders, the media and community. In advertising campaigns environmental issues can be focused. Press releases can be send to local media, which will publicize the unique employee beneflts. Every employee communication must be green.

6. It is important to review what employees have already done and should advertise them while you can focus to rewrite the descriptions of the jobs in order to highlight the ecological aspects of a position.

7. The concept should be explained to senior management through data collection. Example: Gathering information about whether quality job seekers accept job offers due to the ecological 
benefits of the organization. The human resources professional can make a point to ask the candidates how important those benefits were for their decision.

8. They can choose an ecological theme for events such as the health fair for employees; benefitsregistration fair, parties, recognition ceremonies, including staff meetings.

9. Benefiting the employees to understand the real value of green benefits.

10. Employees, the public and the media can generally see through an organization's attempts to exaggerate its benefits and green practices. Publish what companies are doing.

\section{MODEL OF GREEN HRM:}

The HRM have taken many steps to go green which includes green printing, going paperless, reduce commuting, creating an eco-friendly talent, green auditing, recycling the products, Reduction in Business travels for various business deals, creating green policies and finally giving out a green award for the one who has exceedingly performed well in the society.

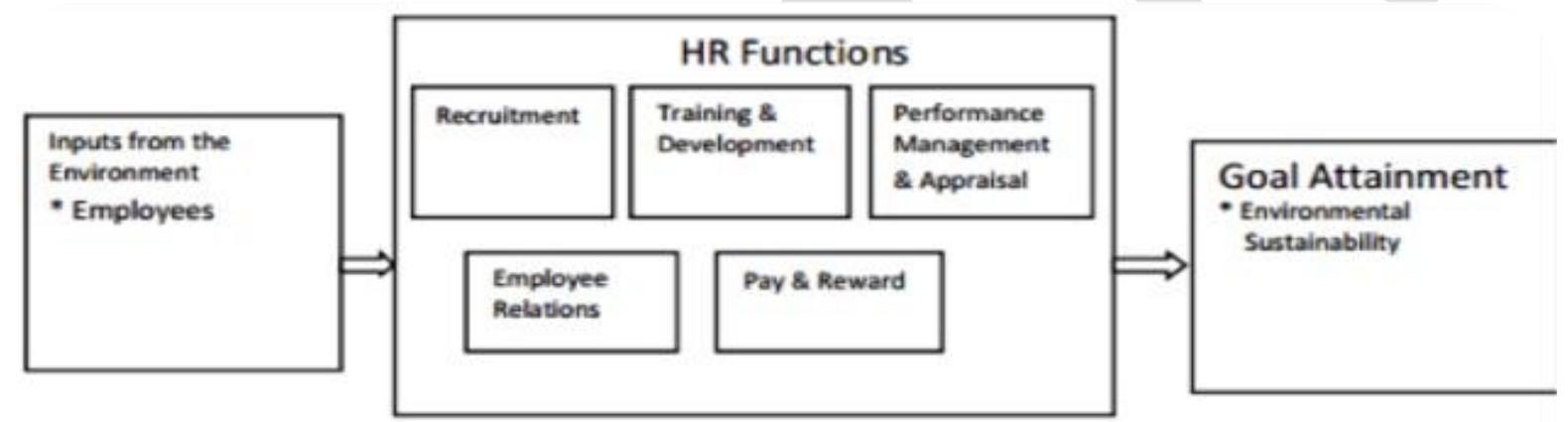

\section{Fig. 1 Model of GHRM}

A process model has been created as a model of Green HRM where in the first step is been taken by the employees. The employees are observing many problems and imbalances in the environment so they can take steps to make certain changes in their workplace so they can contribute a little for the maintenance of the environment. So,for continuing the same thing the HR Department have taken steps towards the same goal and have made certain changes in the functions of HR which includes:

Recruiting - Online Telephonic or may be video calling - using Skype.

Training and development - Providing online training - reduce the cost of the organisation and provide a better understanding of the employee.

Performance Management and Appraisal-Giving the known recognition as green reward to the best employee who performed the same at the workplace which becomes an appraisal for the employee.

Employee Relations - E-Mailing the Employees for the e-birthday wishes and for all the festivals so that they can maintain a connect for the employees.

Pay and reward -In GHRM the management tends to pay the employee'ssalary directly in the account and continuous rewards are given on online basis so that the time and energy is saved for the employees. 


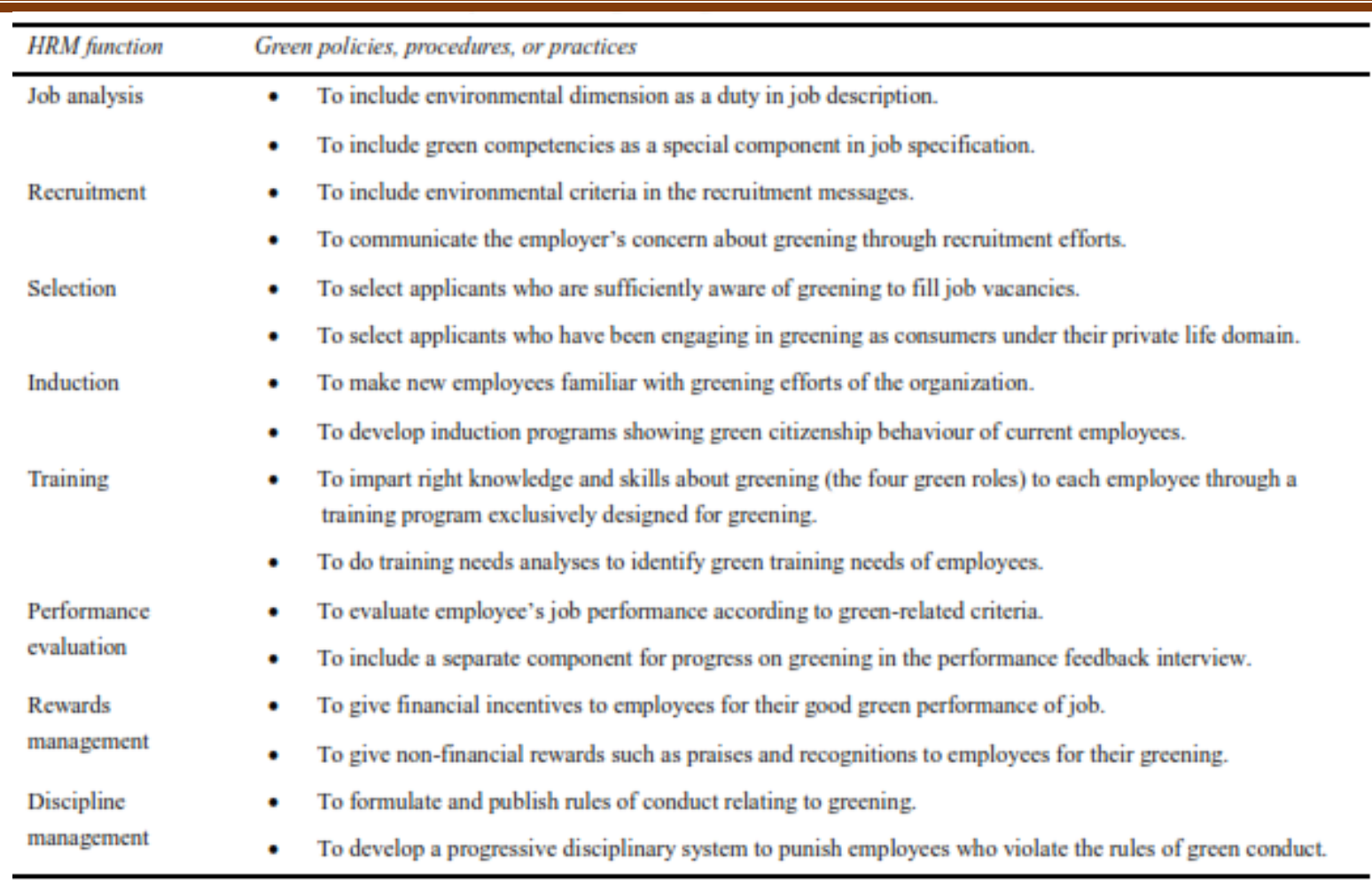

\section{HRM functions - considering green policies, procedures or practices}

The above figure shows various functions of HR and the green policies, procedures and practices been taken place and some changes small changes in the behaviour of the employees can create a great impact all related stakeholders.

\section{CHALLENGES IN GHRM:}

There are various advantages that a worker and association can achieve by actualizing green HRM which includes: Change rate of maintenance in worker, enhancing open picture, change in pulling in better workers, change in profitability, change in maintainable utilisation of assets, decrease of practices that cause the corruption of the earth, decreased utility costs, discounts and tax benefits and expanded business opportunities.

Apart from these mentioned advantages there are some challenges been face by HRM for following the GHRM policies:

1. It's difficult to alter the behaviour of employees in a short span of time and even its difficult to convince the employees for changing their behaviour towards environmental behaviour.

2. HR professionals faces problems of being expected to provide the essential green structures, green processes, green tools and green thinking to make the best selection and develop the future green leaders of the organisation.

3. Sourcing and recruitment of green employees with quality talent is challenging.

4. HR professionals have a crucial role to play in recruitment of new employees who are more responsible towards green business practices. 
5. The whole transformation process is a burdensome and lingering process.

6. Not every employee is equally motivated to participate in the promotion of green HRM practices in the organisation.

7. It requires high investment at initial stage and comparatively slow rate of return.

8. It is difficult to measure the effectiveness of green HR practices in employee's behaviour.

The Green HRM involves specific HR policies and practices aligned with three sustainability pillars-
a. Environment
b. Social and
c. Economic Balance

Inspite of such challenges the following are the different companies which have adopted the GHRM policies:

1. General Electrics: Uses Six Sigma techniques for optimizing their operations to improve environmental and social outcomes in a manner that increases overall performance.

2. Google: Uses green recruitment technique- Believes that most talented people get attracted because of it.

3. Infosys: E- recruitment staffing solutions.

4. Hewlett Packard: Product take back programs, green packing and integrating designs.

\section{CONCLUSIVE REMARKS:}

Green ideas and concepts are beginning to gain momentum within the human resources space, often complementing existing initiatives based on sustainability. Increasingly, they are delivering tangible benefits to the business, rather than simply adding a shine to the brand and reputation. These new processes, policies, products and tools help ensure compliance and improve productivity as well. And now that there is legislation to effectively formalize the need for a new corporate approach to the environment, now is the time for human resources to adopt the green agenda.

Companies can also make additions to their holiday discount plan to offer holiday companies that operate in an environmentally friendly manner, and to their volunteer program. For example, to volunteer in schools, to help students to carry out environmental projects. Some of the company's actions have been very simple, but still very effective (at least to raise awareness), for example, allowing employees to buy a cup of coffee in the coffee bar instead of using disposable cups, and Then receive 10p of a cup of coffee.

The organization can also launch a carbon credit card; Employees receive points for taking public transportation or walking to work, or by videoconference instead of taking a flight. Prizes can be awarded to people with the most points.

Here are several areas where companies can incorporate more environmentally conscious strategies such as using the Internet or teleconferencing to reduce business trips, putting online the employee manuals, policies or other information of the company to reduce the Print. 


\section{BIBILIOGRAPHY:}

1. Alshuwaikhat,H. M.,\&Abubakar,I.(2008). An integrated approach to achieving campus sustainability: assessment of the current campus environmental management practices. Journal of Cleaner Production, 16, 1777-1785. http://dx.doi.org/10.1016/j.jclepro.2007.12.002

2. Bamberg, S.(2003). How does environmental concern in fluence specific environmentally related behaviors? A new answer to an old question. Journal of Environmental Psychology, 23,21-32. http://dx.doi.org/10.1016/S0272-4944(02)00078-6

3. Bamberg, S., \& Moser G.(2007). Twenty years after Hines, Hunger ford, and Tomera: A new meta-analysis of psycho-social determinants of pro-environmental behaviour. Journal of Environmental Psychology,27,14-25. http://dx.doi.org/10.1016/j.jenvp.2006.12.002

4. Barrett, S., \& Murphy, D. (1996). Managing Corporate Environmental Policy. In W. Wehrmeyer (Ed.), Greening People (pp.75-98).

5. Daily, B.F., \& Huang, S. (2001). Achieving Sustainability Through Attention to Human Resource Factors in Environmental Management. International Journal of Operation and Production Management, 21(12), 1539-1552. http://dx.doi.org/10.1108/01443570110410892

6. Garavan, T.N., Heraty, N., Rock, A., \& Dalton, E. (2010). Conceptualizing the Behavioral Barriers to CSR and CSin Organizations: A Typology of HRD Interventions. Advances in Developing Human Resources, 12(5), 587-613. http://dx.doi.org/10.1177/1523422310394779

7. Jackson, S.E., Renwick, W.S., Jabbour, C.J.C., \& Muller-Camen, M.(2011). State-of-theArt and Future Directions for Green Human Resource Management: Introduction to the Special Issue. German Journal of ResearchinHumanResourceManagement,25(2),99-116.

8. Milliman,J., \& Clair,J. (1996). Best Environmental HRM Practices in the US. In W.Wehrmeyer (Ed.), Greening People, Human Resources and Environmental Management. Sheffield: Green leaf Publishing.http://dx.doi.org/10.9774/GLEAF.978-1909493-00-1_4

9. Ramus,C.A.(2001). Organizing support for employees: Encouraging creative ideas for environmental sustainability. California Management Review, 43 (3), 85-103. http://dx.doi.org/10.2307/41166090

10. Shrivastava, P. (1994). CASTRATED Environment: GREENING Organizational Studies. Organization Studies, 15(5),705-726. http://dx.doi.org/10.1177/017084069401500504 